\title{
LVII. Remarks on the weather during the quarter ending September 30, 1848
}

\section{James Glaisher Esq.}

To cite this article: James Glaisher Esq. (1848) LVII. Remarks on the weather during the quarter ending September 30, 1848, Philosophical Magazine Series 3, 33:223, 365-376, DOI: $10.1080 / 14786444808646122$

To link to this article: http://dx.doi.org/10.1080/14786444808646122

册 Published online: 30 Apr 2009.

Submit your article to this journal $₫$

Џ Article views: 2

Q View related articles $₫$ 
LVII. Remarks on the Weather during the Quarter ending September 30, 1848. By James Glaisher, Esq., of the Royal Observatory, Greenwich*.

TTHE meteorological returns for the past quarter furnished 1 to the Registrar-General have been obtained from the usual places. These have been all examined and discussed by myself in the same manner as detailed in the previous Numbers of the Philosophical Magazine. The following are my remarks upon the weather of the past quarter.

With the exception of a few days in July, and the period between the 9th and 23rd of September, the weather during the quarter ending September 30, 1848, was wet, with very little sunshine. The month of August was extremely wet, and in many places the falls of rain both in July and September were unusually great. So much rain falling in a period immediately following the previous bad weather, renders the season and the year very remarkable. On July 1 the mean temperature of the air was $8^{\circ} \cdot 4$ below the average value from the seven preceding years, and on the 6 th it was $12^{\circ} .2$ in excess above the average ; on the former day the mean temperature was $46^{\circ} \cdot 7$, and on the latter day it was $74^{\circ} \cdot 0$. On the 9 th it was $3^{\circ}$ below the average, and on the 14 th it was $9^{\circ} \cdot 4$. above the average; and on the 15 th it was again below the average. These changes were large and abrupt. From July 11 to September 19 the temperature of the air was almost always below the average value, and particularly so between the 11 th and the 15th of September; on the 12th the departure from the average was $12^{\circ} \cdot 6$. From the 20 th of September to the end of the quarter, the temperature of the air ranged somewhat above the average value.

The hottest day in this year was July 6, and this day was the hottest all over the country. On an average of seven years, the hottest day is July 5.

In pursuance of the arrangement hitherto followed, I will speak of each subject of investigation separately.

The mean temperature of the air at Greenwich-

For the month of July was $61^{\circ} \cdot 5$, which is $3^{\circ} \cdot 7,1^{\circ} \cdot 3,0^{\circ} \cdot 6$, $0^{\circ} \cdot 1$, and $1^{\circ} \cdot 7$ above those of the years 18411 to 184.5 respectively, $3^{\circ} .0$ and $3^{\circ} .9$ below those of the years 1846 and 184.7 ; or it is $0^{\circ} .1$ above the average of these seven years;

For the month of August was $58^{\circ} \cdot 5$, which is $2^{\circ} \cdot 0,6^{\circ} \cdot 9$, $3^{\circ} \cdot 6,4^{\circ} \cdot 7$, and $3^{\circ} \cdot 6$ below those of the years $1841,1842,1843$, 184.6 , and 184.7 respectively, $0^{\circ} \cdot 8$ and $1^{\circ} \cdot 2$ above those of the years 1844 and 1845 respectively; or it is $2^{\circ} \cdot 7$ below the average of these seven years;

* Communicated by the Author. 
For the month of September was $55^{\circ} \cdot 8$, which is $2^{\circ} \cdot 3,0^{\circ} \cdot 6$, $3^{\circ} \cdot 7,1^{\circ} \cdot 1$, and $4^{\circ} \cdot 3$ below those of the years $1841,1842,1843$, 184.4; and 1847 respectively, $1^{\circ} \cdot 2$ and $1^{\circ} \cdot 5$ above those of the years 1845 and 1846 respectively; or it is $1^{\circ} \cdot 2$ below the average of these seven years.

The mean value for the quarter was $58^{\circ} 6$; that for 1841 was $58^{\circ} .8$; for 181.2 was $60^{\circ} \cdot 7$; for 1843 was $60^{\circ} .8$; for 1844 was $58^{\circ} \cdot 7$; for 1845 was $56^{\circ} \cdot 9$; for 1846 was $62^{\circ} \cdot 6$; and for 1847 was $60^{\circ} .3$; so that the defect for this quarter below the corresponding quarter in the years 1841, 1842, 1843, 1844, 1846 , and 1847 , was $0^{\circ} \cdot 2,2^{\circ} \cdot 1,2^{\circ} \cdot 2,0^{\circ} \cdot 1,4^{\circ} \cdot 0$, and $1^{\circ} \cdot 7$ respectively; the only year between 1841 and 1847 whose mean temperature for this period was less than that for the present year was 1845 , and the difference is $1^{\circ} \cdot 7$. The average value for this quarter from the seven preceding years was $59^{\circ} 8$; so that the mean temperature of the air for the quarter ending September 30, 1848, was below that of the corresponding quarter in the preceding seven years by $1^{\circ} \cdot 2$.

The mean temperature of evaporation at Greenwich-

For the month of July was $57^{\circ} \cdot 6$, which is $0^{\circ} \cdot 1$ above that for the preceding seven years;

For the month of August was $55^{\circ} \cdot 2$, which is $2^{\circ} \cdot 9$ belorw that for the preceding seven years;

For the month of September was $53^{\circ} .2$, which is $1^{\circ} .5$ beloro that for the preceding seven years.

The mean value for the quarter was $55^{\circ} \cdot 3$, which is $1^{\circ} \cdot 4$ below the average for the seven preceding years.

The mean temperature of the derw-point at Greenroich-

For the month of April was $54^{\circ} \cdot 6$, which is $3^{\circ} \cdot 0,1^{\circ} \cdot 4,0^{\circ} \cdot 2$, $1^{\circ} \cdot 9$, and $1^{\circ} \cdot 8$ below those for the years $1841,184.2,1845,1846$, and 1847 respectively, $1^{\circ} \cdot 7$ and $0^{\circ} \cdot 1$ above those for the years 1843 and 1844 respectively; or it is $0^{\circ} .9$ above the average of these seven years;

For the month of August was $52^{\circ} \cdot 8$, which is $2^{\circ} \cdot 2,6^{\circ} \cdot 1$, $5^{\circ} .0,4^{\circ} \cdot 7$, and $3^{\circ} \cdot 3$ below those for the years 1841, 1842, 1843,1846 , and 1847 respectively, $0^{\circ} \cdot 5$ and $0^{\circ} \cdot 2$ above those for the years 184.4 and 1845 ; or it is $2^{\circ} \cdot 9$ below the average for these seven years;

For the month of September was $50^{\circ} \cdot 9$, which is $2^{\circ} \cdot 8,2^{\circ} \cdot 6$, $4^{\circ} \cdot 0,2^{\circ} \cdot 3$, and $4^{\circ} \cdot 0$ below those for the years 1841,1842 , 1843,1844 , and 1846 respectively, $1^{\circ} .2$ above those of the years 1845 and 1847 ; or it is $1^{\circ} .9$ below the average of these seven years.

The mean value for the quarter was $52^{\circ} \cdot 8$, which is $1^{\circ} \cdot 3$ below the average for the corresponding period of the preceding seven years.

The mean weight of water in a cubic foot of air for the 
quarter was 4.5 grains, which is 0.2 grain less than the average for the seven preceding years.

The additional reight of rater required to saturate a cubic foot of air was $1 \cdot 1$ grain. The average value for the seven preceding yerrs was $1 \cdot 0$ grain.

The mean degree of humidity of the atmosphere for July was 0.762, for August was 0.797 , and for September was 0.795. The averages for the seven preceding years were 0.780 , 0.804 , and 0.84 .2 respectively. The value for the quarter was 0.785 , which is 0.024 less than the average for these years.

The mean elastic force of vapour for the quarter was 0.411 inch, which is 0.026 less than the average for these years.

The mean reading of the barometer at Greenwich for July was 29.836 inches, for August was 29.732 inches, and for September was 29.832 inches; these values are 0.041 inch above, 0.065 inch below, and 0.021 inch above respectively the averages for the seven preceding years. The mean value for the quarter was $29 \cdot 797$ inches, which is of the same value as the average for the seven preceding years.

The average weight of a cubic foot of air under the average temperature, humidity, and pressure, was 527 grains; the average for the seven preceding years was 526 grains.

The rain fallen at Greenwich in July was $2 \cdot 1$ inches; in August was $4 \cdot 6$ inches; and in September was $2 \cdot 4$ inches; the average amount for the seven preceding years was 2.3 inches in July, 2:7 inches in August, and 2.2 inches in September. The amount fallen in the quarter was $9 \cdot 1$ inches, which is 1.9 inch greater than the average for the seven preceding years. The average fall of rain during this quarter, as derived from the observations since the year 1815 , is 7 inches. In the year 1824 the fall of rain in the quarter ending September 30 was 9 inches, in 1828 it was 12.5 inches, in 1829 it was 11 inches, and in 1839 it was 10.5 inches. The total amount of rain fallen this year till September 30 was 24.3 inches; in 1841 it was 21.9 inches; in 1842 it was 14.2 inches; in 184.3 it was 17.5 inches; in 1844 it was 16.2 inches; in 1845 it was 16.6 inches; in 1846 it was 17.5 inches; and in 1847 it was 11.6 inches. So that the fall of rain this year exceeds that in 1841 by $2 \cdot 7$ inches; in 184.2 by 9.7 inches; in 184.3 by 6.4 . inches; in 1844 lby 7.7 inches; in 1845 by 7.3 inches; in 1846 by 6.4 inches; and in 1847 by 12.3 inches. The excess of the fall of rain this year over the average for the seven preceding years is 7.5 inches.

In the years 1824 and 1828 the depth of rain fallen to the end of September exceeded 23 inches; and in the years 1829 and 1839 the amount collected exceeded 20 inches. So large 
a fall as 24.3 inches within the first nine months of the year has probably not been exceeded within this century.

The temperature of the woater of the Thames was $63^{\circ} .0$ by day, and $62^{\circ} .0$ by night. The water, on an average, was $3^{\circ} .9$ warmer than the air.

The horizontal movement of the air was about 130 miles daily; during the period of time between July 19 and July 27 it amounted to 233 miles per day; from July 31 to August 6 its average daily value was 240 miles; and on August 21 it exceeded 300 miles.

The highest and lowest readings of the thermometer in Air at the height of four feet above the ground, and protected as much as possible from the effects of radiation and rain, were $85^{\circ} \cdot 3$ and $32^{\circ} \cdot 8$.

The average daily ranges of the readings of the thermometer in Air at the height of four feet, were $22^{\circ} .5$ in July, $18^{\circ} .5$ in August, and $20^{\circ} \cdot 9$ in September. The average ranges for these months from the observations of the seven preceding years were $17^{\circ} \cdot 2,17^{\circ} \cdot 1$, and $16^{\circ} \cdot 2$ respectively.

In July the readings of the thermometer on grass were $29 \cdot 5$ on one night; between $32^{\circ}$ and $40^{\circ}$ on nine nights; between $40^{\circ}$ and $50^{\circ}$ on twelve nights; and above $50^{\circ}$ on nine nights.

In August the lowest reading was $36^{\circ}$ : and the readings were below $40^{\circ}$ on four nights; between $40^{\circ}$ and $50^{\circ}$ on eighteen nights; and above $50^{\circ}$ on nine nights.

In September the readings were below $32^{\circ}$ on nine nights, and the lowest was $23^{\circ}$; they were between $32^{\circ}$ and $40^{\circ}$ on seven nights; between $40^{\circ}$ and $50^{\circ}$ on nine nights; and ạbove $50^{\circ}$ on four nights.

The mean amount of cloud for July was $6{ }^{\bullet}$, for August was $7 \cdot 6$, and for September was $5^{*} 6$. The average values for the seven preceding years were $6 \cdot 7,6 \cdot 3$, and $6 \cdot 0$ respectively.

There were five exhibitions of the aurora borealis during the quarter, which occurred on July 11, August 28, September 4,8 and 18.

Thunder-storms at different parts of the country occurred on July 14, 26, August 1, 3, 4, 5, 6, 7, 8, 9, 10, 11, 22, 23, 31, and September 5 ; and lightning unaccompanied by thunder was seen on July 24, August 23, 24, 25, September 22 and 25. The storms of July 14 were observed at Greenwich, Latiner Rectory, Cardington, Saffron Walden and Leicester. At Greenwich, thunder-clouds were observed first in the west and north-west at $8^{\mathrm{h}} 30^{\mathrm{m}}$ P.M. ; and from this time till near midnight the thunder followed the lightning at intervals varying from $5^{8}$ to $40^{\mathrm{s}}$; and lightning was visible during the whole of the night. At Latimer the storm is described as awful, and 
of five hours' duration. On July 24, lightning was seen at Saffron Walden; on July 26 there was a thunder-storm at Leicester; on August 1, thunder was heard at Greenwich during the afternoon; on Angust 3 and 4 at Saffron Walden; on August 5 there were thunder-storms at Greenwich, Stone, Saffron Walden, Leicester and Empingham. Near the lastmentioned place a tree was struck by the lightning.

On $A$ ugust 6 and 7 there were thunder-storms at Leicester; on August 8 at Leicester and at Exeter; on August 9 at Greenwich, but no lightning was seen; on August 10 at Stone ; on August 11 at Greenwich, between the hours of 6 and 8 P.M.; the storm began in the east, and many of the flashes of lightning were vivid, and preceded the thunder by two or three seconds only. On August 22 there were storms at Exeter, Stone, Saffron Walden, Cardington, and at Leicester. At Greenwich, on August 23 and 24, between the hours of 8 P.M. and midnight, on both days many flashes of lightning were seen. On August 31, at Greenwich and at Stone, there were thunder-storms; at the former place the thunder followed the lightning at intervals varying from $1^{\mathrm{s}}$ to $12^{\mathrm{s}}$. On September 5 there were storms at Greenwich, Stone and Leicester; on September 22 lightning was seen at Greenwich and at Stone, and again at Stone on the 25th.

Hail fell at Stone and Cardington on August 22, and at Empingham on August 5; the hailstones at Cardington were of very large dimensions.

Gales of wind took place all over the country on August 20, 21 and 22 , but more particularly on the 21st. At many places trees were blown down, and a great deal of injury was done; coasting-vessels and fishing-boats generally suffered very much.

Large and continuous falls of rain. - In July, at Greenwich, rain fell to the depth of 0.3 inch on the 15 th, 23rd and 31 st. On the 14th, at Latimer Rectory, rain to the depth of half an inch fell in half an hour. In August rain was falling more or less at every part of the country on every day. At Greenwich the amount collected exceeded 0.3 inch on the $1 \mathrm{st}, 3 \mathrm{rd}$, 8 th, 10 th and $21 \mathrm{st}$; and the falls exceeded 0.7 inch on the 14th and 31 st; on the 14th a large fall occurred at all places. In September, on the 24th, at Thwaite, between $4^{\mathrm{h}}$ A.M. and $9^{\mathrm{h}}$ A.M., rain fell to the depth of 2.12 inches, a greater fall within the same interval of time than has occurred at Thwaite within the preceding forty years; and on this day, at Leeds, the fall within nine hours was 2 inches. Cn the $28 \mathrm{th}$, 29th and 30th days, rain was falling almost continuously over all parts of the country. At Cardington the fall within sixty hours was $2 \cdot 6$ 
inches. At Leicester the amount within seventy-two hours was 2.25 inches, and this was the amount which fell on these days at most places. This large fall, extending over so large a portion of the country, was most unusual.

The approximate mean monthly values of the several subjects of research are shown in extensive tables in the report of the Registrar-General.

The mean monthly temperatures of the places in Cornwall and Devonshire in these three months are about the same values as those of other places, but the extremes of daily and monthly temperatures are much less than elsewhere.

The reading of the barometer was low at the beginning of July, being 29.403 inches at $6^{\text {h }}$ A.M. on the 1st; this reading increased to $29^{\circ} 740$ by $6^{\text {h }}$ P.M. on the $2 \mathrm{nd}$; decreased to 29.611 on the 3rd, and increased quickly on the 4th, and reached 30 inches before midnight on this day. The reading ranged above 30 inches on the 5 th, and decreased to $29 \cdot 635$ by midnight on the 9 th. During the loth the value increased 0.539 inch, having passed the point 30 inches at about $1^{\text {h }}$ P.M. on this day. The reading continued above 30 inches till the 17 th ; the highest value was 30.344 on the 12th. From the 17 th there was a gradual decrease to $29 \cdot 146$ on the 20 th at $3^{\mathrm{h}}$ P.M. ; at midnight on this day the reading was $29 \cdot 467$, and increased to $29 \cdot 781$ on the 24 th ; during the 25 th the decrease was 0.300 inch, and the reading was $29^{\circ} 480$ at midnight; it then gradually increased to 30 inches by the 29 th. On the 30 th the change was considerable, amounting to half an inch during the day ; and at the end of the month the reading was 29.313 inches, and still decreasing.

On August 1st, at $6^{\mathrm{h}}$ A.M., the reading was $29 \cdot 244$ inches; after this time it turned to increase, and was 29.581 at midnight, and reached 29.817 on the 2 nd day. On the 3 rd it decreased, and was 29.582 at midnight; during the 4 th the changes were small; on the 5 th the decrease was 0.190 inch, and the reading at midnight was 29.335 inches. During the 6 th and 7 th there was a slight increase. From this time to the 20th the changes were small, and at midnight on the 20th the reading was $29 \cdot 846$ inches. The decrease on the 21 st was 0.334 inch, and at noon on the 22 nd the reading was $29 \cdot 4.23$ inches, when it turned to increase, and was 29.528 at midnight; the increase continued till the 25th at noon, the reading at this time being $29 \cdot 947$, when it turned to decrease, and the changes after this time to the end of the month were small.

In September, till the 4 th, the reading was above 30 inches; during the 5 th it decreased 0.2 inch, and was 29.638 at mid- 
night; from the 6 th to the 9 th the changes were small; on the 10th, by P.M., the reading decreased 0.219 inch, and the reading was 29.496 inches; it then turned to increase quickly; on the 11th the reading at midnight was 30.091 inches. From this time till the 18 th the reading was always above 30 inches; the highest value was 30.345 on the 16 th. On the 19th it began to decrease, and on the 24 th the reading was 29.223 inches; and from this time to the end of the month the changes were small, and chiefly about the mean reading of $29^{\prime} 6$ inches.

The great prevalence of rain during the quarter, together with the very short periods of sunshine, have harassed the farmer in gathering in the crops. The month of July was about its usual character, but the constant rain in August impeded the farmer in his operations, and in many of the southern counties injured the crops considerably, causing the corn to sprout and seed-leaves to appear, of fully an inch in length, by the middle of August; the greater coldness of the northern counties prevented the sprouting of the corn, but it otherwise was seriously injured.

Between the 9th and the 23rd of September the weather was generally fine, and this period was the only good interval of time for harvest work during the quarter, and the wheat gathered within this time was in good condition. The heavy falls of rain at the end of this month flooded many parts of the country, and the roads in some places were deeply arenched.

John Fletcher Miller, Esq., of Whitehaven, says, "The harvest in this neighbourhood was completed by September 20 , somewhat earlier than usual. The crops were abundant, and secured in excellent condition."

Charles Charnock, Esq., of Leeds, says, "The harvest has been most protracted, and there is yet much both of barley and oats out in the fields, which $I$ fear is seriously injured. There is in fact much more corn out in the northern districts than is generally supposed. On September 25 I observed in the East Riding of Yorkshire hundreds of acres of corn and potatoes with water to the depth of a foot upon them. The wheat and barley, which were housed between the 9 th and the 23rd of September, were without damage and in good condition; that which was housed before this time was in a bad state from not being dry. Wheat in this neighbourhood has not sprouted generally. Wheat and barley yield badly, and both crops are under an average. Both oats and beans are average crops. Potatoes are getting worse; the winter or late varieties of this vegelable are now attacked and rotting very fast; roherever the tops have been very luxuriant they are the worst. I have observed that the disease seems to have 
been immediately preceded by a white frost, which disease I have no doubt is attributable to meteorological causes.

"Sheep stock has not been healthy; the deaths among the lambs have been very numerous even in the driest districts."

Samuel Charles Whitbread, Esq., says, "My harvest began on the 28th of July; it continued forty-two days, and rain fell on twenty-eight of these days, depositing 4.75 inches of water; on the whole the crops suffered no damage." This remark has reference to the crops in Bedfordshire.

The observer at Stone says, speaking of the crops in the Vale of Aylesbury, "that those of hay and clover were abundant and good, but were not well-gathered; that wheat was below an average of many years, but was well-housed; that both barley and oats were average crops, and they were wellhoused." 'The observer speaks of the potato crop as being generally bad.

John Drew, Esq., F.R.A.S., of Southampton, has kindly procured me an agricultural report from John Clark, Esq. of Finsbury Farm, near Romsey, Hampshire, and which I have condensed into the following few lines.

The South Hampshire farmer has been subjected during the past quarter to more trying dispensations of Providence than Mr. Clark has experienced within a period of twenty-five years' practice. This gentleman further observes that the almost constant wet weather has injured every kind of crop, and that but little has come to maturity. The occasional short periods of sunshine have frequently induced the hope that a season would come for haymaking and harvest work, but which expectation unfortunately has never been realized. A large quantity of hay has been consequently rendered useless, and turnips have been very much injured. The wide range of prices of new wheat affords the best evidence of the extent to which this crop has been harassed. On those lands which have been well-farmed and well-drained, or on those which would readily part with an excess of moisture, the crops are an average (with the exception of potatoes, which are almost a failure). On heavy cold soils the crops are below an average. In consequence of the exceeding wetness cattle have done badly.

The recent heavy rains (now Oct. 6) excite great anxiety with respect to seed-time. On wet lands a great deal is needed to be done to prepare them for sowing, which operation must be late, and therefore to a certain extent more precarious than if performed under the more favourable circumstances of a good seed season.

Themean of the numbers in the first column of the subjoined quarterly meteorological table is 29.541 inches, and this value 
may be considered as that of the pressure of dry air for England during the quarter ending September 30, 1848. The differences between this number and the separate results contained in the first column, show the probable sums of the errors of $\mathrm{ob}$ servation and reduction; the latter arising partly from erroneously assumed altitudes, and partly in consequence of the index error of the instruments not having been determined. In most cases, however, the sums of these errors are small.

'The mean of the numbers in the second column, for those places situated in the counties of Cornwall and Devonshire, is $58^{\circ} \cdot 1$; for those places situated south of latitude $52^{\circ}$, including Chichester and Hartwell, is $57^{\circ} \cdot 8$; for those places situated between the latitudes of $52^{\circ}$ and $53^{\circ}$, including Saffron Walden and Highfield House, was $56^{\circ} \cdot 8$; for those places situated between the latitudes of $53^{\circ}$ and $54^{\circ}$, including Liverpool and Whitehaven, but not Stonyhurst, whose mean temperature, from its greater elevation, is lower than that due to its latitude alone, was $56^{\circ} \cdot 2$; and for Durham and Newcastle was $55^{\circ} .8$. This value, however, is somewhat too high for the former place and too low for the latter, on account of the difference of elevation of these places. These values may be considered as those of the mean temperature of the air for these different parallels of latitude during the quarter ending September 30, 1848.

The average daily range of the temperature of the air in Cornwall and Devonshire was 14.2; at Liverpool and Whitehaven was $10^{\circ} \cdot 2$; south of latitude $52^{\circ}$ was $19^{\circ} .5$; between the latitudes of $52^{\circ}$ and $53^{\circ}$ was $15^{\circ} \cdot 8$; between the latitudes of $53^{\circ}$ and $54^{\circ}$ was $15^{\circ} \cdot 9$; and of Durham and Newcastle was $14^{\circ} .4$.

The greatest mean daily ranges of the temperature of the air took place at Hartwell, Latimer, Aylesbury and Leicester respectively; and the least occurred at Liverpool, Whitehaven, Torquay and Truro respectively.

The highest thermometer readings in air during the quarter were $95^{\circ}$ at Leicester, $90^{\circ}$ at Wakefield, and $89^{\circ}$ at Hartwell; but it seems highly probable that these readings are greater than the temperature of the air really reached. The reading $88^{\circ}$ seems to be confirmed, and this value may be considered as the highest during the quarter. The lowest values of the thermometer readings in air were $29^{\circ}$ at Hartwell, $31^{\circ}$ at Latimer and Cardington. The extreme range of temperature of the air during the quarter was therefore about $59^{\circ}$.

The average quarterly range of the reading of the thermometer in Cornwall and Devonshire was $33^{\circ .2}$; at Liverpool and Whitehaven was $32^{\circ} .5$; and the mean of the numbers at all the other places is $49^{\circ}, 2$. The highest and lowest readings 


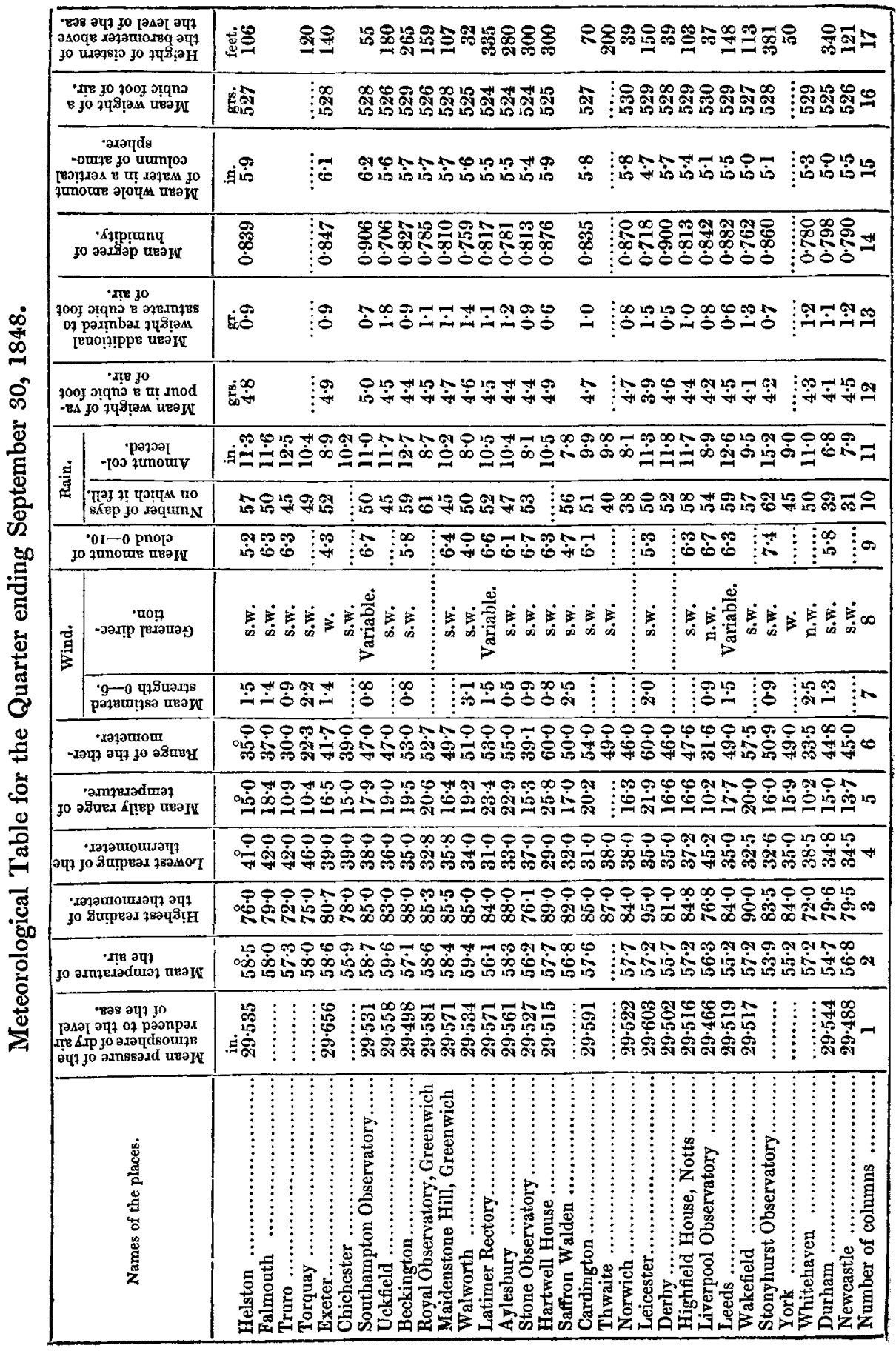


at Stone, and all depending upon them, are evidently erroneous.

From the numbers in this quarter, as well as those of preceding quarters, it would seem that the Vale of Aylesbury is subject to greater extremes of temperature than any other part of the country of equal extent.

The great mass of air has passed from the south-west in all places except Liverpool and Whitehaven, at both of which places it seems to have passed from the north-west. By reference to the Monthly 'Table, it will be seen that this was particularly the case in July and August; but in September the direction of the wind was frequently from the east, and its compounds.

From the numbers in the ninth column, the distribution of cloud seems to have been nearly the same in amount at most places, and such as to have covered about three-fifths of the whole sky.

The fall of rain during the quarter has greatly exceeded the average amount for the season, and this was particularly the case in the month of August. The places at which rain has fallen on the greatest number of days were Stonyhurst, Greenwich, Beckington, Leeds, Highfield House, Helsion and Wakefield, and the average number of these places was 59 ; and the places at which rain fell on the least number of days are those situated near the eastern coast. The places at which the largest falls have taken place were Stonyhurst, Hereford, Beckington, Leeds and Torquay. The places where the falls have been the least in amount are Durham, Newcastle, Saffron Walden, Walworth, Stone and Norwich. The amount at Stone being so much less than the fall at adjacent places, seems to be strange; and this was the case in the preceding quarter, in consequence of which the Rev. J. B. Reade, on August 17, wrote to me, stating that "there had been many electrical clouds giving copious showers around us, especially on the Chiltern Hills and in the neighbourhood of Aylesbury, while we were in sunshine. This was particularly the case yesterday afternoon."

The numbers in column 12 to 16 show the mean values of the hygrometrical results at every station; from which we find that-

The mean weight of vapour in a cubic foot of air for England (excepting Cornwall and Devonshire) in the quarter ending September 30,1848 , was $4 \cdot 5$ grains.

The mean additional weight required to saturate a cubic foot of air in the quarter ending Sept. 30, 184.8, was 1'0 grain.

The mean degree of humidity (complete saturation =1) in the quarter ending September 30, 1848, was 0.815. 
The mean amount of vapour mixed with the air would have produced water, if all had been precipitated at one time on the surface of the earth, to the depth of 5.5 inches.

The mean weight of a cubic foot of air at the level of the sea, under the mean pressure, temperature and humidity, was 529.3 grains.

And these values for Cornwall and Devonshire were 4.8 grains ; 0.9 grain $0.843 ; 6.0$ inches; and 530 grains respectively.

LVIII. Account of the Aurora Borealis as seen at Stonyhurst Observatory, October 1848. By the Rev. Alfred Weld, B.A., of Stonyhurst College*.?

$\mathrm{N}$ the evening of this day I was fortunate enough to witness the most magnificent display of aurora borealis which has been known in this part of the country for many years. The following are the principal features as they were noticed at the Observatory of Stonyhurst.

At about $6^{\text {h }} 45^{\mathrm{m}}$ P.M. it was observed that the sky in the N.E. was tinged with crimson, and at the same time an arc of light was seen stretching from N.N.E. to a point about the N.W. From this arc great numbers of faint rays were emitted in both directions. By degrees the whole of that portion of the heavens became filled with rays of light, which were spread in confusion over the sky, some arising immediately from the horizon, others having their origin at different altitucles: none of these were remarkable for length or intensity of light. In the meantime the red in the N.E. was increasing to a brilliant crimson, remaining perfectly fixed, except that it extended itself northward like a great cloud of fire, and assumed a very magnificent appearance, while the streamers and sheets of light between the N. and N.W. underwent rapid changes, exhibiting now a somewhat irregular inverted arch, and now wound into a wreath so as to enclose an almost perfect circle. Shortly after seven the spectacle was very grand; from N.E. to S.W. the whole sky, to the altitude of $30^{\circ}$ or $40^{\circ}$, was filled with sheets and streamers of light, all nearly steady (if we except a certain tremulous motion which seemed to animate the whole mass), and chiefly of a brilliant crimson hue.

During this time the cloud of red light continued stationary in the N.E., in the constellation Auriga, the principal

* Communicated by the Author. 